\title{
A taxonomic revision of Grevillea angulata (Proteaceae: Grevilleoideae) and closely related species from the Northern Territory and Western Australia
}

\author{
Peter M. Olde and Neil R. Marriott
}

\begin{abstract}
Olde, Peter M. (138 Fowler Rd, Illawong, NSW, Australia 2234) \& Marriott, Neil R. (White Gums Nursery, Deep Lead, VIC, Australia 3377). A taxonomic revision of Grevillea angulata (Proteaceae: Grevilleoideae) and closely related species from the Northern Territory and Western Australia. Telopea 5(2): 399-417. Three new species of Grevillea (G. aurea, G. brevis and G. glabrescens) are separated from G. angulata R.Br. One new species (G. microcarpa) is separated from G. agrifolia A. Cunn. ex R. Br. G. angulata var.? lancifolia F. Muell. ex Benth. is referred to synonymy under G. brevis. Notes on affinities and distribution are included as well as a key to the group.
\end{abstract}

\section{Introduction}

The phenetically similar species G. angulata R. Br. and G. agrifolia A. Cunn. ex R. Br. were first described by Robert Brown (1830: 24) from collections by Allan Cunningham. Bentham (1870: 422) included both species in his Section 4, Calothyrsus, a diverse group of mainly tropical species. At the end of his treatment of G. angulata (p. 455), he added 'Var.? lancifolia' with brief description, locality, and collection details. Subsequently, Ewart \& Rees (1911: 68) described G. agrifolia var. major from a specimen collected at Napier Broome Bay, Western Australia, by G.F. Hill. McGillivray (1975) lectotypified the names Grevillea agrifolia and G. angulata and at the same time referred G. agrifolia var. major to synonymy under G. agrifolia. In 1986, pending publication of fuller details in his revision of the genus (McGillivray 1993), and in order to validate the new name, McGillivray briefly described G. prasina, which had, till then, usually been identified as G. angulata R. Br.

McGillivray (1993: 210-214) gives a very extensive morphometric analysis of G. agrifolia, G. angulata and G. prasina. Populations referable to our G. microcarpa are there discussed but are included in a widened circumscription of G. agrifolia. Phenotypic groupings referable to G. angulata s. str. as well as to our G. aurea, G. brevis and $G$. glabrescens are also briefly discussed but are included in a very broadly circumscribed G. angulata within which our G. aurea is treated informally as the 'goldenflowered form'.

These treatments, both formal and informal, comprise the published taxonomic literature on the G. angulata group to this time.

Recent collections and further study of existing specimens at NSW, DNA, CANB, CBG and PERTH show that homogeneous populations currently accommodated within G. angulata by McGillivray (1993) form the basis for the recognition of three new species. In addition, one new species is recognised from specimens currently identified as G. agrifolia. All new species share a close relationship with both $G$. angulata and G. agrifolia but are each as morphologically distinct as G. prasina. Both G. angulata and $G$. agrifolia are more narrowly circumscribed than previously but, even after the separation of the new species, remain variable species.

Codes used to indicate conservation status follow Briggs \& Leigh (1988). 


\section{Morphology}

Species descriptions follow the format used by McGillivray (1993). Leaf width refers to the widest measurement on a leaf, including excurrent lobe spines. The terms 'brochidodromous' and 'mixed craspedodromous' are used where appropriate to describe the pattern of leaf venation, following Hickey (1973). Both terms allude to variations of what is basically pinnate venation. In brochidodromous venation the secondary or lateral veins never terminate at the margin but rather loop submarginally in a series of prominent arches to the next most distal secondary vein. In mixed craspedodromous venation some of the secondary veins terminate at the margin and an approximately equal number do not; these usually branch submarginally with the branches following the margin to the next most distal secondary vein which terminates at the margin.

Inflorescence terminology conforms with definitions in Johnson \& Briggs (1975) and Briggs \& Johnson (1979). Accordingly, the term 'conflorescence' is used to describe the aggregation of bracteate, pedicellate 2-flowered uniflorescences, the main axis of which is always anauxotelic and often ramified. The term 'unit conflorescence' follows Makinson (1991: 31) and is used where appropriate to denote either a simple (non-ramified) conflorescence or the individual ramifications of a ramified conflorescence, with all measurements taken on the ultimate rachis. Perianth shape and revolution of limb are judged on flowers of the conflorescence immediately before anthesis i.e. those standing on the rachis immediately behind those in which anthesis has occurred. Perianth length is the distance from the mid-point of the torus to the top of the flower. Perianth width refers to the widest measurement across the lower half of the tube, perpendicular to the plane of dorsiventral symmetry. Pistil length includes that portion of the stipe enclosed within and adnate to the torus (usually $0.5-1 \mathrm{~mm}$ ) as well as the style-end. The style-end refers to the expanded apical portion of the style to which the pollen-presenter is attached. For fruit measurements, length refers to the measurement from the apex to the base, width refers to the measurement of the planar distance from the dorsal to the ventral suture at its widest point, depth refers to the measurement from side to side, perpendicular to the width.

Indumentum is termed 'dense' when the underlying epidermis is obscured and 'sparse' or 'moderately sparse' when the lamina is visible, the former being relatively less dense than the second. Hairs are either glandular or non-glandular. Non-glandular hairs are either simple (e.g. on the inner perianth surface) or biramous (two-armed) and usually medifixed (e.g. elsewhere on the conflorescences, branchlets and leaves).

Measurements have been made on both live and dried, unsoftened specimens and have been cross-checked, where relevant, with those given by McGillivray (1993). All taxa have been seen in the field. 


\section{Discussion}

G. angulata and related species herein described form a distinct group among the tropical Grevillea species, having the following major identifying features in common: gregarious, shrubby habit; leaves dorsiventral with concolorous lamina usually $>5$ $\mathrm{mm}$ wide on each side of the midvein, margins flat and sometimes also undulate; unit conflorescences conico-cylindrical with development acropetal, usually decurved; floral bracts caducous; torus oblique; nectary prominent, hippocrepiform (horseshoeshaped) with the margin occasionally smooth but usually bi- or tridentate; pistil clearly exceeding the perianth at anthesis; ovary glabrous, stipitate; pollen-presenter oblong to obovate, oblique at $65-70^{\circ}$; fruits verruculose; seed membranously peripterous with conspicuous raphe. Perianth development is also significant within this group. At or before anthesis, G. aurea excepted, the tepals separate, while remaining united at the limb; the dorsal tepals then reflex and become aligned with the ventral tepals, which also separate from each other and become everted. An open platform comprised of the four separated and everted tepals is thus formed (Figure 1a) that serves possibly as an aid or guide to pollinators. In G. aurea, perianth shape remains coherent except along the dorsal suture which separates through exsertion of the style, with separation greater towards the limb (Figure 1e).

Less significant features, common to all species but excluded from the species descriptions, are leaves ascending to spreading; conflorescences simple to 2-branched, usually axillary, sometimes terminal on subterminal branchlets; torus slightly cupuliform; nectary partially enclosed within and adnate to the torus, but extending $0.5-0.8 \mathrm{~mm}$ above the toral rim; ovary c. $1 \mathrm{~mm}$ long, globose to ovoid, oblique to lateral; outer surface of fruit glabrous, the style deciduous; seed smooth and convex on the outer face.

The G. angulata group as here defined is almost certainly monophyletic. The closest affinities of the group are with another tropical group of phenetically similar species that comprises G. wickhamii Meissn., G. byrnesii McGillivray, G. velutinella McGillivray and G. miniata W.V. Fitzg. This group differs principally in its flowers having the style about the same length as the perianth and the pollen-presenter lateral. A third group of related species, as we see it, comprises G. adenotricha McGillivray, G. cunninghamii R. Br., G. longicuspis McGillivray and G. benthamiana McGillivray. In this group the ovarian stipe is usually lateral to the torus (and therefore roughly at right angles to the line of the pedicel) and conflorescences, with the exception of G. benthamiana, are subglobose and prominently pedunculate. A fourth group, united either by a sublinguiform, conspicuously toothed nectary and/or the tepal-limbs prominently flanged at the tepal margins or carinate, includes G. dryandri R. Br., G. latifolia C. Gardner, G. pungens R. Br., G. refracta R. Br., G. versicolor McGillivray and perhaps $\mathrm{G}$. heliosperma $\mathrm{R}$. Br. 


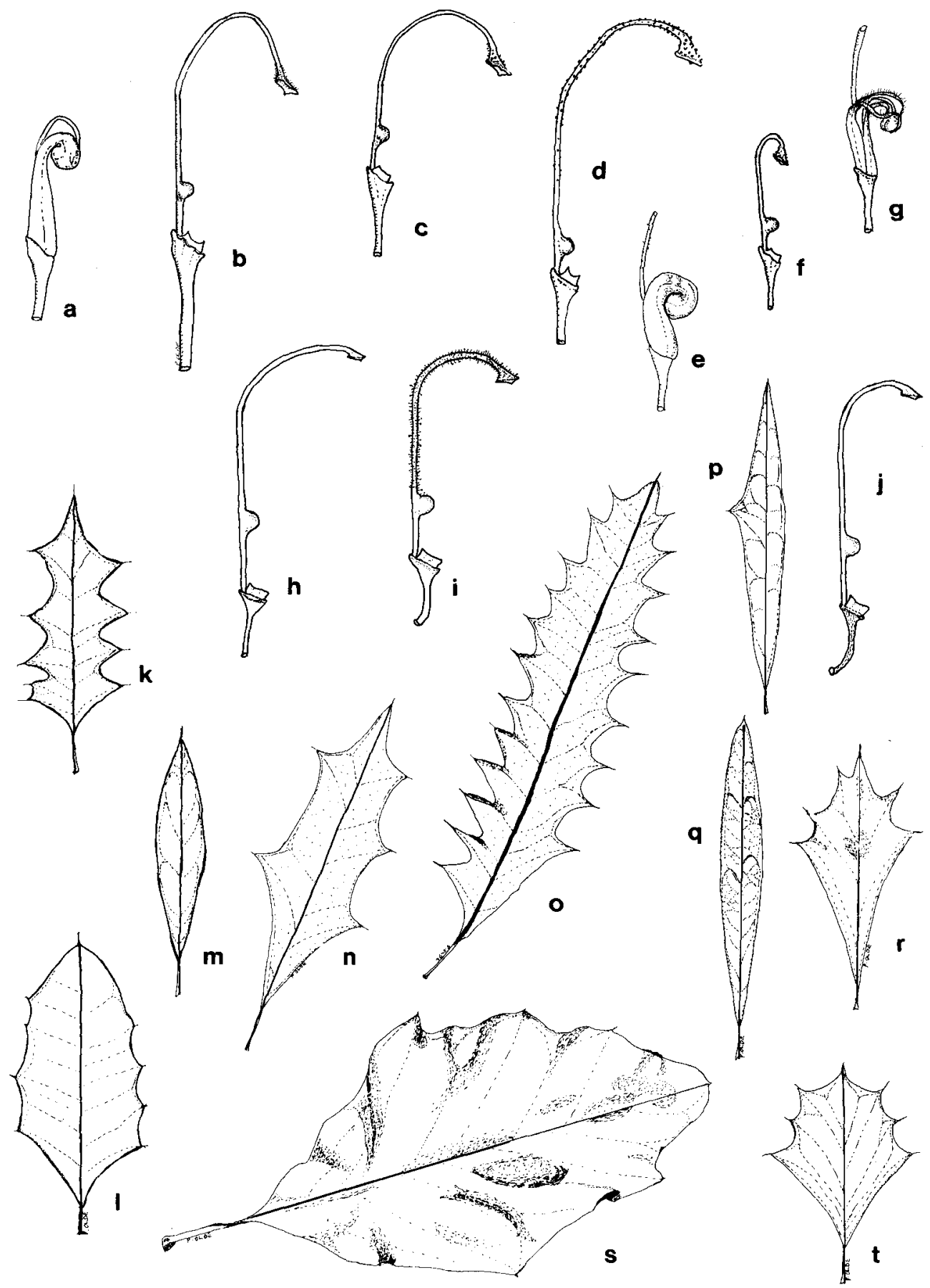

Figure 1. Flowers and leaves of the G. angulata group. G. angulata: a, perianth shape before anthesis (typical of group); $\mathbf{b}$, pistil; $\mathbf{k}, \mathbf{l}$, typical leaf forms; $\mathbf{m}$, simple leaf. G. glabrescens: $\mathbf{c}$, pistil; $\mathbf{n}$, typical leaf. G. aurea: d, pistil; $\mathbf{e}$, perianth shape at anthesis; $\mathbf{o}$, typical leaf. G. brevis: $\mathbf{f}$, pistil; $\mathbf{g}$, perianth after anthesis (typical of group); $\mathbf{p}, \mathbf{q}$, typical leaves. $G$. prasina: $\mathbf{h}$, pistil; $\mathbf{r}$, typical leaf. G. agrifolia: $\mathbf{i}$, pistil; $\mathbf{s}$, typical leaf. G. microcarpa: $\mathbf{j}$, pistil; $\mathbf{t}$, typical leaf. (Leaves all $\times 0.5$; flowers all $\times 2$ ). 


\section{Key to group}

1 Adult leaves either entirely glabrous or, rarely, with a few scattered hairs

2 Style-end lacking hairs or granules; branchlets sharply angular and ridged; habit lignotuberous, usually with many stems

5. G. prasina

$2^{*}$ Style-end hairy or granulate; branchlets slightly angular or round; habit single-stemmed

3 Pistil $>15 \mathrm{~mm}$ long; most leaves $>2 \mathrm{~cm}$ wide, 2-24-toothed

4 Dorsal tepals not or scarcely reflexing at anthesis; unit conflorescence $4-16 \mathrm{~cm}$ long; perianth strongly revolute, $2-3 \mathrm{~mm}$ wide, mostly yellow to gold; style usually granulate from the apex for at least half its length

3. G. aurea

$4^{*}$ Dorsal tepals reflexing markedly to reveal the inner surface at anthesis; unit conflorescence $2-4 \mathrm{~cm}$ long; perianth revolute in the upper half, $1.5-2 \mathrm{~mm}$ wide, green to white; style granulate in the apical few $\mathrm{mm}$

2. G. glabrescens

$3^{*}$ Pistil < $13 \mathrm{~mm}$ long; most leaves $<1.5 \mathrm{~cm}$ wide, 0 -3-toothed

4. G. brevis

$1^{*}$ Adult leaves bearing a moderately sparse to dense, often inconspicuous indumentum on one or both surfaces

5 Mature fruits 18-23 mm long; pericarp 2.8-4.6 mm thick at centre-face; most leaves $>4 \mathrm{~cm}$ wide; style usually with an inconspicuous, spreading indumentum over most of its length

6. G. agrifolia

$5^{*}$ Mature fruits $<15 \mathrm{~mm}$ long; pericarp $<1.5 \mathrm{~mm}$ thick at centre-face; most leaves $<4 \mathrm{~cm}$ wide; style either entirely glabrous or with a sparse indumentum.

6 Style-end granulate, papillose or with short erect trichomes; outer perianth surface glabrous

1. G. angulata

$6^{*}$ Style-end smooth, glabrous; outer perianth surface hairy or glabrous

7 Leaf indumentum dense; branchlets angular to round; leaves olive-green to grey-green

7. G. microcarpa

$7^{*}$ Leaf indumentum sparse; branchlets sharply angular; leaves bright green

5. G. prasina

\section{Grevillea angulata $R . B r$. \\ (Brown 1830: 24)}

Lectotype (McGillivray 1975: 24): 'G. ilicifolia Cunningh. Mermaid's 1st Voyage No. 163 Sim's Island North Coast' (label on lower left of sheet), 'Nova Hollandia Cunningham in King's 1st Voyage' (data on reverse side of sheet at top) (BM, photo seen). IsOlecto: E (n.v.), NSW 113768, G-DC (n.v.), K (n.v.).

Seedlings (McGillivray 3913 \& Dunlop): cotyledons opposite, oblong, obtuse, auriculate at the base, midvein faintly developed, first two leaves obovate, sessile, subopposite, 
entire to 5-toothed, third leaf 9-toothed, fourth leaf 13-toothed, fifth leaf 17-toothed; hypocotyl c. $3 \mathrm{~cm}$ long, terete, glabrous, faintly ridged. Juveniles: young foliar buds and leaves rusty sericeous. Adults: spreading to spindly, single-stemmed shrubs, prostrate in subcoastal situations, $0.1-2.5 \mathrm{~m}$ tall; branchlets angular and ridged becoming rounded with age, sericeous with mixed rusty and white biramous trichomes; leaves green, flat to slightly sinuate, $2-12 \mathrm{~cm}$ long, $1.5-3.5(-5) \mathrm{cm}$ wide, including petioles $2-10 \mathrm{~mm}$ long, glabrous or sparsely minute-sericeous above, on the undersurface bearing an open indumentum of closely appressed minute trichomes, either (Type Form) oblong-ovate to obovate with 2-10 subopposite, broadly triangular, spine-tipped lobes (spines c. $1 \mathrm{~mm}$ long, brittle, scarcely pungent) and sinuses shallow-arcuate to rectilinear, rarely entire, elliptic to obovate with an apical spine 2 $\mathrm{mm}$ long or (Narrow-leaved Form) oblong with (2-)10-24 subopposite, triangular, spinetipped lobes per side (spines c. $2 \mathrm{~mm}$ long, rigid, pungent) and sinuses strongly arcuate; apex acute, pungent; base cuneate to spreading; venation prominent on both surfaces, mixed craspedodromous with conspicuous reticulum on toothed leaves, brochidodromous on entire leaves. Unit conflorescence $(1-) 3-5(-6) \mathrm{cm}$ long, dense to loose; primary peduncle $1-4 \mathrm{~cm}$ long, sericeous; floral rachis glabrous to sparsely sericeous; bracts $0.5-1 \mathrm{~mm}$ long, $0.5-1 \mathrm{~mm}$ wide, ovate, ciliate, otherwise \pm glabrous; pedicels 3.5-5 mm long, glabrous, spreading to retrorse at anthesis; torus c. $2 \mathrm{~mm}$ across, oblique at c. $45^{\circ}$. Perianth 5-10 $\mathrm{mm}$ long, 2-3 $\mathrm{mm}$ wide, narrowly attenuateovoid, revolute in the upper half, glabrous outside, densely white-bearded inside, the trichomes mostly 1-1.5 mm long and usually extending onto the attenuated portion of the inner tepal surface; dorsal tepals separating markedly from the ventral tepals and reflexing strongly at anthesis; limb $1.5 \mathrm{~mm}$ long, $2.5 \mathrm{~mm}$ wide, spheroidal. Pistil (16-)18-24 mm long; stipe (2.5-)3-5 mm long; style smooth, glabrous except for tubercles, granules and/or scattered biramous trichomes confined to the apical 2-3 $\mathrm{mm}$, rarely occasional trichomes produced on lower sections of the style (Jacobs 1849); style-end not dilated beyond the base of the pollen-presenter; pollen-presenter convex; stigma central to slightly off-centre. Fruit 10-14 mm long, 8.5-10.5 mm wide, 8-9.5 mm deep, obovoidal to ellipsoidal, usually adaxially transverse to the stipe with the sutures directed outwards, sometimes only slightly oblique; pericarp 1-1.2 $\mathrm{mm}$ thick at centre face. Seeds $6-7 \mathrm{~mm}$ long, $3.5 \mathrm{~mm}$ wide, obovoidal to ellipsoidal, convex on the inner face; wing 1-2 mm wide. Figure $1 \mathrm{a}-\mathrm{b}, \mathrm{k}-\mathrm{m}$.

FLOWER COLOUR: Perianth green in bud maturing through white to cream or pale yellow. Style and style-end green at anthesis ageing to pale yellow. The flowers are sweetly scented.

\section{FLOWERING PERIOD: March-September.}

DistRiBution: Grevillea angulata is confined to the offshore islands and northern mainland Northern Territory extending south to and east from the East Alligator River. The locality 'Port Darwin' (Holtze, 1911) has never been verified and is probably not strictly accurate.

Conservation status: Not considered to be at risk. G. angulata is included in Kakadu National Park only at its northern periphery.

HABITAT AND ECOLOGY: Occurs in eucalypt woodland in sandy soils, or at the top of laterite cliffs in sandy loam and in the lee of such cliffs in sandy dune; occasionally, near Nabarlek, on low sandstone outcrops. The species is killed by severe fire and regenerates from seed. However, following low-level burn-offs, it possibly also regenerates from epicormic buds on the stems, like most of the shrubby flora of the area (obs. P. Olde). Mayali Aboriginal people (Oenpelli area) indicate that the species is a source of nectar for bees, which may be a possible pollinator, although we believe the most successful pollinators are probably nectarivorous birds (cf. our observations 
of G. agrifolia on page 414). The Mayali refer to G. angulata as 'anbirrim', a general name for Grevillea species with prickly-toothed leaves (Chaloupka \& Giuliani 1968). The timber reportedly makes good firewood (Smyth \& von Sturmer 1981).

Discussion: Grevillea angulata is here more narrowly circumscribed than in McGillivray (1993). It is distinguished by its densely sericeous branchlets; green, oblong, elliptic to obovate adult leaves $1.5-3.5(-5) \mathrm{cm}$ wide, bearing a sparse to moderately sparse, closely appressed, minute (trichomes c. $0.1 \mathrm{~mm}$ long) indumentum on one or both surfaces, usually pungently toothed, rarely entire; perianth glabrous outside, white at anthesis, dorsal tepals separating from ventral tepals before anthesis and reflexing markedly to reveal a conspicuous, densely villous beard on the inner surface the longest trichomes of which are $>1 \mathrm{~mm}$ long; pistil (16-)18-24 mm long, ovarian stipe (2.5-)3-5 mm long, tubercles, granules, papillae or occasional biramous trichomes confined to the apical $2 \mathrm{~mm}$ of the style; fruits $10-14 \mathrm{~mm}$ long, oblique to almost perpendicular to the stipe, pericarp 1-1.2 $\mathrm{mm}$ thick at centre of the suture.

VARIATION: G. angulata is loosely divided into two forms based on leaf characters and minor floral differences but formal infraspecific status is not warranted. The type form has obovate to oblong, broad (2-5 cm wide) leaves with shallow, rectilinear or shallow-arcuate sinuses, fewer lobes (usually 2-10) with spines c. $1 \mathrm{~mm}$ long. Conflorescences are relatively dense and usually $2-4 \mathrm{~cm}$ long. This form occurs on the islands, the mainland coast and up to $50 \mathrm{~km}$ inland from the northern coastline and is represented by collections from Sims Island, Goulburn Island, Brogden Point, extending up to $50 \mathrm{~km} \mathrm{~S}$ of Murgenella. Prostrate plants of this form occur on laterite cliffs east of Murgenella. Two collections (Ross 3279 and Brock 69) have entire, elliptic to obovate leaves but are otherwise assignable to the type form. These collections, from Brogden Point and near Murgenella, are from unusual plants and not from distinct, separate populations (cf. Briggs 8108 and K. Hill 3975 from the same area with toothed leaves).

Plants from around Oenpelli, i.e. at the southern end of the distribution, here termed the narrow-leaved form, have oblong leaves usually $1.5-2.5 \mathrm{~cm}$ wide, with 8-24 lobes tipped with spines c. $2 \mathrm{~mm}$ long and strongly arcuate sinuses. The conflorescences are generally slightly longer (3-5 cm long) and slightly looser.

Selected SPECIMENS (from 40 examined): NORTHERn TERRITORY: Type form: Goulburn Island, $5 \mathrm{~km}$ E of Barge Landing, Wightman 3153 \& Smith, 14 Oct 1986 (DNA 28566); Brogden Point, Ross 3279, 27 Aug 1987 (CBG); Murgenelia North Rd, Murgenella, Brock 69, 24 Jan 1985 (DNA 26763); Brogden Point, Arnhem Land, Briggs 8108, 27 Aug 1987 (NSW 206461, DNA, K, PERTH); 1 km S Brogden Point, Hill 3975 \& Stanberg, 31 Aug 1991 (NSW 246097, DNA, CANB, BRI); laterite cliffs east of Murgenella on coast, Olde 92/16, 5 Jul 1992 (NSW, DNA, CBG, PERTH); 10 miles (16 km) W of Gningarg Point, Cameron \& Rance s.n., 1 Oct 1973 (DNA 16142); Gningarg Point, Cameron s.n., 1 Oct 1973 (DNA 16143); Brady's Rd, Murgenella, Wightman 1931, 9 Jul 1985 (DNA, NT, CANB, BRI, NSW, MEL, K- n.v.); Port Darwin, Holtze, Mar 1911 (NSW 26985, PERTH); $36.7 \mathrm{~km} \mathrm{~S}$ of Murgenella on road from Oenpelli, Olde 92/09, 5 Jul 1992 (NSW). Narrow-leaved form: $11.3 \mathrm{~km}$ S of road to Nabarlek on Myra Falls Track, Olde 92/18, 6 Jul 1992 (NSW, CBG, DNA, PERTH); WSW of Nabarlek, McGillivray 3910, 10 Jul 1978 (NSW, DNA, PERTH, K, US, CANB, LE, DAR, NY, B, PRE, E, RSA); WSW Nabarlek, seedling, McGillivray 3913 \& Dunlop, 10 June 1978 (NSW); 8 km E East Alligator River Crossing, Dunlop 3704, 11 Jun 1977 (DNA, NSW, MO, K); 12²0'S, $133^{\circ} 13^{\prime} \mathrm{E}$ Lazarides 7554, 6 July 1972 (CANB, DNA, BRI, NSW, K, L, US); Birraduk Creek, 18 km ENE Oenpelli, Cardale s.n., 4 Jun 1973 (CANB); 1.25 miles (2 km) ESE Cannon Hill, Martensz \& Schodde 708, 3 Feb 1973 (CANB, DNA, NT); $10 \mathrm{~km}$ S of Oenpelli, Munir 5860, 24 May 1988 (NSW; AD).

ILLUSTRATIONS: Brock (1986: 198, top plate); Elliot \& Jones (1990: 25). 


\section{Grevillea glabrescens $P$. Olde $\mathcal{E} N$. Marriott, sp. nov.}

$\mathrm{Ab}$ Grevillea angulata ramulis glabrescentibus, foliis glabris dense foveolatisque, ovarii stipite breviore (2-2.5 mm longo), perianthio angustiore (1.5-2 $\mathrm{mm}$ lato) aut omnino glabro intus aut sparse aut inconspicue barbato cum trichomis $<1 \mathrm{~mm} \mathrm{long}$, fructibus plerumque longioribus (14-16 mm longis) distinguitur.

Holotype: Northern Territory: Kakadu National Park: c. $4 \mathrm{~km}$ S of El Sharana, $13^{\circ} 33^{\prime} \mathrm{S}$ $132^{\circ} 30^{\prime}$ E, A.V. Slee 2681 \& L. Craven, 20 April 1990 (CANB). Isotypes: A, BRI, DNA, MEL, NSW.

Seedlings not seen. Juveniles: leaf buds and young leaves rusty-sericeous. Adults: spreading to erect, sometimes open, single-stemmed shrubs, 0.9-2.5 m tall; branchlets angular to rounded, glabrescent; leaves green, flat to slightly sinuate, $(6.5-) 8-11(-13) \mathrm{cm}$ long (1-)2-4 cm wide including petioles c. $10 \mathrm{~mm}$ long, entirely glabrous except for occasional appressed trichomes on the midvein, densely foveolate, oblong in gross outline with 2-10 irregular to subopposite, triangular, spine-tipped lobes (spines 1-2 mm long, pungent or scarcely so) and sinuses deeply and broadly arcuate to rectilinear; apex acute, pungent; base cuneate; venation mixed craspedodromous with conspicuous reticulum. Unit conflorescence $2-4 \mathrm{~cm}$ long, loose, delicate; primary peduncle 1-2 cm long, glabrous, sometimes two peduncles arising in the same axil; floral rachis glabrous; bracts $0.5 \mathrm{~mm}$ long, $0.5 \mathrm{~mm}$ wide, ovate, glabrous, margins sometimes faintly ciliate; pedicels $2.5-4 \mathrm{~mm}$ long, glabrous, spreading to retrorse after anthesis; torus 1-1.5 mm across, oblique at $30^{\circ}$. Perianth $6 \mathrm{~mm}$ long, $1.5-2 \mathrm{~mm}$ wide, narrowly ovoid, attenuate and revolute in the upper half, glabrous outside, conspicuously papillose and mealy inside and either entirely glabrous or with occasional scattered trichomes or quite densely bearded with most trichomes $<1 \mathrm{~mm}$ long; dorsal tepals separating markedly from the ventral tepals and reflexing strongly at anthesis; limb $1.5 \mathrm{~mm}$ long, $1 \mathrm{~mm}$ wide, spheroidal. Pistil 15-20 mm long; stipe 2-2.5 mm long, glabrous; style smooth, glabrous except for tubercles or scattered trichomes extending 2(-3) $\mathrm{mm}$ from the style-end; pollen-presenter convex; stigma distally off-centre. Fruit 14-16 mm long, 10-12 mm wide, $11 \mathrm{~mm}$ deep, ellipsoidal, oblique to adaxially transverse to the stipe with the sutures directed outwards; pericarp $1 \mathrm{~mm}$ thick at centre face. Seeds $8 \mathrm{~mm}$ long, $3 \mathrm{~mm}$ wide, ellipsoidal, flat to slightly convex on inner face with wing 2-2.5 mm wide. Figure 1c, n.

EPITHET: Derived from the Latin glabrescens, becoming glabrous, in reference to the leaves and branchlets, which quickly shed trichomes evident on young growth.

FLOWER COLOUR: Perianth green, ageing white at anthesis to cream after pollination. Style green ageing cream with green style-end. Flowers are sweetly scented.

FLOWERING PERIOD: Dependent on length of wet season. Specimens in flower have been collected in all months of the year except December. However, in 1992, most flowering had finished by July.

Distribution: G. glabrescens occurs from Graveside Gorge south to about $10 \mathrm{~km} \mathrm{~S}$ of El Sharana in Kakadu National Park. The distribution is separated by over $100 \mathrm{~km} \mathrm{SW}$ from the most southerly collection of G. angulata.

CONSERvation status: $2 \mathrm{RCt}$ is recommended until the area is fully surveyed. All known populations are within Kakadu National Park.

HABITAT AND ECOLOGY: Found exclusively on the sandstone escarpment either in low heath at the top or just below the top, on the slopes, in valleys, or beside dried creek beds. It grows in sandy, rocky and shallow soils or in cracks and crevices. Regeneration after fire is unknown but presumably plants regenerate from seed. Some regen- 
eration from epicormic buds on the stem can be expected following low-intensity fires. Pollinator unknown, probably either birds or bees or both.

Discussion: Of the newly described species, the one most closely related to G. angulata is G. glabrescens. It differs in its glabrous or sparsely sericeous branchlets, its usually entirely glabrous, densely foveolate, adult leaves, usually with more irregular toothing, its looser, more delicate conflorescences, its shorter ovarian stipe (2-2.5 $\mathrm{mm}$ long), its narrower perianth $(1.5-2 \mathrm{~mm}$ wide) and the perianth beard either absent or sparsely or inconspicuously developed on the inner perianth surface with the longest trichomes usually $<1 \mathrm{~mm}$ long and in its usually larger fruits.

Serious consideration was given to describing $G$. glabrescens as a subspecies of $G$. angulata on the grounds that the differences may be due to ecotypic effects of the more inland sandstone pavement on which this taxon is found. Indeed, most quantitative measurements abut those of $G$. angulata. However, the close relationship of all taxa in this group together with the consistent and readily observable distinguishing features of G. glabrescens, especially when compared to G. prasina, has persuaded us that specific ranking is appropriate for this taxon which occurs in homogeneous populations over a relatively wide area of the Kakadu escarpment.

VARIATION: A relatively uniform species. There is some variation in the degree of bearding on the inner perianth surface which ranges from absent to quite dense.

SELECTED SPECIMENS (from 20 examined): NORTHERn TERRITORY: $3-5 \mathrm{~km} \mathrm{~W}$ of South Alligator River, Olde 92/34, 10 July 1992 (NSW, DNA, CBG, PERTH); 2-3 miles (3-5 km) N of El Sharana, Martensz \& Schodde AE 567, 25 Jan 1973 (CANB, K, DNA); UDP Falls, South Alligator River, Byrnes 1376, 20 Feb 1969 (DNA, NSW, NT); Waterfall Creek, Dunlop 5604 \& Jones, 27 Nov 1980 (NSW, DNA); above U.D.P. Falls, Gittins 2631, July 1973 (NSW, PERTH, NT, K); top of Gunlom Falls (formerly UDP Falls), Kakadu National Park, Johnstone 158, 20 July 1989 (NSW, PERTH, B, RSA, NBG); near Kurundie Creek, Kakadu National Park, Leach 2810 \& Cowie, 20 Apr 1990 (DNA, CANB, NSW); Waterfall Creek, Wightman 1278 \& Dunlop, 19 Apr 1984 (DNA, NSW); tributary of Barramundi Creek, Djalkurumburr, Thompson 513, 30 Jun 1983 (CANB, NSW, US); Graveside Gorge, Cowie 277, 2 Jun 1985 (DNA 27080).

IlLUSTRATION: Brennan (1986: 14, pl. 8 [as G. angulata]).

\section{Grevillea aurea $P$. Olde $\mathcal{E} N$. Marriott, sp. nov.}

Grevilleae angulatae affinis, sed foliis glabris foveolatisque, conflorescentiis longioribus (plerumque $4-10 \mathrm{~cm}$ longis sed saepe usque ad $16 \mathrm{~cm}$ longas), ovarii stipite breviore (1.5-2(-2.8) $\mathrm{mm}$ longo), aut tuberculis aut granulis aut trichomis secus stylum saepe distributis, perianthio forte recurvato inconspicue barbato intus cum trichomis plerumque $<1 \mathrm{~mm}$ longis, tepalis dorsalibus sub anthesi non reflexis, fructibus erectis, differt.

Holotype: Northern Territory: Deaf Adder Gorge, $13^{\circ} 06^{\prime} \mathrm{S} 132^{\circ} 56^{\prime} \mathrm{E}$, along creek running north into the gorge, c. $10 \mathrm{~km}$ from the mouth, D.J. McGillivray $3934 \mathcal{E}$ C. Dunlop, 17 July 1978 (NSW). IsotYPEs: DNA, PERTH, K, US, LE, B, RSA, CANB, PRE.

Seedlings (J. Forlonge s.n.): cotyledons opposite, oblong-obovate, obtuse, auriculate at the base, midvein and lateral veins faintly developed, margin shortly recurved; hypocotyl $3 \mathrm{~cm}$ long, terete, bearing sparse patent trichomes; first two leaves subopposite, ovate to elliptic, entire or 1 tooth per side; third leaf alternate, irregularly 2-3-toothed, third leaf more regularly 5-toothed. Juveniles: leaves brown-sericeous, the lamina often bearing cells with brown to red contents. Adults: erect, single-stemmed shrubs 2-3.5(-6) $\mathrm{m}$ tall; branchlets angular to slightly flattened, becoming rounded with age, sometimes longitudinally ridged, densely to sparsely subsericeous with 
mixed white and fawnish two-armed trichomes. Leaves green to blue-green, (5-)7-16 $\mathrm{cm}$ long, $1.5-4.5 \mathrm{~cm}$ wide, including petioles $7-22 \mathrm{~mm}$ long, entirely glabrous except for a few scattered trichomes sometimes evident on the midvein, oblong with (2-)8-24 usually subopposite, triangular, spine-tipped lobes (spines $2 \mathrm{~mm}$ long, pungent) and sinuses strongly arcuate; upper and lower surfaces sparingly to densely foveolate; apex acute, pungent; base cuneate to spreading; venation prominent on both surfaces, mixed craspedodromous with conspicuous reticulum. Unit conflorescence 4-16 cm long, sometimes cauline, loose to dense, sometimes lax and curved down in the distal half; primary peduncle $2.5-3.5 \mathrm{~cm}$ long, sericeous; floral rachis glabrous to sparsely sericeous; bracts $0.6-1.5 \mathrm{~mm}$ long, $0.5-1.5 \mathrm{~mm}$ wide, ovateacuminate to obovate, glabrous sometimes with ciliate margins; pedicels 4-8 $\mathrm{mm}$ long, glabrous, markedly retrorse at anthesis; torus $1.5-2 \mathrm{~mm}$ across, oblique at $30-45^{\circ}$. Perianth 5-7 mm long, 2-3 mm wide, \pm coherent, slightly dilated at the base, strongly curved with the apex of the limb adjacent to the lower perianth, glabrous outside, inconspicuously bearded inside, most trichomes $<0.5 \mathrm{~mm}$ long and confined to the lower half of the perianth, papillose in the upper half; dorsal tepals scarcely separate from the ventral tepals, not reflexing at anthesis; limb $2 \mathrm{~mm}$ long, $2.5 \mathrm{~mm}$ wide, conspicuous, dominant in early bud, ovoid-spheroidal. Pistil 17-23 mm long; stipe 1.5-2 mm (rarely $2.8 \mathrm{~mm}$ Lazarides 7860 ) long, glabrous; style glabrous or sparsely to prominently covered with granules or tubercles and occasional trichomes (granules sometimes evident on ventral surface only) ; style-end granulate or papillose, slightly dilated 1-2 mm from the apex; pollen-presenter convex; stigma distally off-centre. Fruits 10-17 mm long, 7-11 mm wide, 8-11 mm deep, ellipsoidal, erect or slightly oblique; pericarp 1-1.3 mm thick at centre face. Seeds 7-11 mm long, 3-4 mm wide, obovoidal-ellipsoidal, inner face \pm flat with marginal curvature and rim evident; wing 1.5-3 mm wide. Figure $1 \mathrm{~d}-\mathrm{e}$, o.

EPITHET: Derived from the Latin aureus, golden, in reference to the usual flower colour.

FLOWER COLOUR: Perianth usually orange-red to yellow, sometimes cream to creamy yellow. Buds red to orange. Style cream to orange. Citation from type label: 'Inflorescences orange from a distance. Pedicels yellow; perianth yellow with green lines along upper margins of tepals; nectary yellow; stipe cream; ovary brownish-green; style greenish-brown at the base becoming brownish orange at the apex; pollenpresenter green tinged with orange at the edge'.

FLOWERING PERIOD: March-September.

DistRibution: G. aurea is known from three areas; at latitude of $12^{\circ} 31^{\prime} \mathrm{S}$ (the most northerly) north-east of Jabiru; in the Graveside Gorge - Deaf Adder Gorge - Gilruth Creek area; and north-west of Barramundi Gorge.

Conservation status: G. aurea occurs wholly within Kakadu National Park and is not considered at risk.

HABITAT AND ECOLOGY: The type collection was made in deep sand beside a stream, but elsewhere G. aurea occurs in rocky talus on sandstone or at the top of sandstone plateaux in open heath or heathy forest. Lazarides 7860 was collected from a lateritic mesa in grey, pebbly sand with Triodia. Most collections have been from the top of the sandstone escarpment. Brennan (1986) reports its habitat as stony slopes in the upper reaches of creek and river catchments. Pollinator unknown, probably birds. Regenerates from seed after fire (pers. obs.)

Discussion: G. aurea approaches both G. glabrescens and G. brevis in its floral and foliar morphology but is distinguished from them by numerous features, either separately or in combination, but not always constantly. The most obvious distinguishing 
feature is the golden-yellow flower colour, often partially preserved on dried specimens, which immediately separates the taxon visually. More significantly, in G. aurea, the dorsal tepals remain more or less erect at anthesis leaving the perianth shape coherent and the inner surface concealed. In all other species of the group the dorsal tepals separate and reflex to reveal the inner tepal surface at anthesis. All specimens of G. aurea have the trichomes of the inner perianth beard c. $0.5 \mathrm{~mm}$ long, and on dried specimens, the beard appears inconspicuous. Other distinguishing features are its densely sericeous branchlets (cf. G. glabrescens), leaves usually entirely glabrous and often densely foveolate, the often longer conflorescences (up to $16 \mathrm{~cm}$ long), the significantly shorter ovarian stipe $(1.5-2(-2.8) \mathrm{mm}$ long), the distribution of tubercles, granules or trichomes beyond the apical $2 \mathrm{~mm}$ of the style onto its lower half (sometimes indistinct and sparse, rarely absent), the style-end more noticeably thickened, the perianth very strongly recurved and usually broader at the base, fruits usually more erect and both fruits and seeds also often longer than for other related species.

One plant in a population of G. glabrescens near Djalkurumburr (Olde 92/35) shows some evidence of hybridisation with $G$. aurea, mainly in its green buds with some coppery colouration, the creamy-yellow flower after anthesis and its densely sericeous branchlets. The geographic distribution of the two species overlaps at this point and, as other collections of yellow rather than gold flowered forms of G. aurea are also known from this area, some gene flow between the two taxa is suggested.

VARIATION: There is some variation between populations. Plants from north-east of Jabiru are recorded as having yellow flowers on inflorescences shorter $(<5 \mathrm{~cm}$ long) than seen elsewhere. The narrowest leaves are also noted on specimens from this area. In the Deaf Adder Gorge - Gilruth Creek area, most collections are uniform, bearing long conflorescences with red-budded, golden flowers. The broadest leaves, usually with longer stem internodes, occur on plants in this area. Some specimens from the area NW of Barramundi Gorge have leaves with less regular lobing and fewer lobes per side (2-6). Some specimens have a very sparse to absent stylar indumentum (Craven 2427, Craven 6393 from the same area) although, on all other characters, they clearly belong to this species. Lazarides 7860 is anomalous in having leaves with longer more attenuate apical lobes, ovarian stipes up to $2.8 \mathrm{~mm}$ long and tepals looser than those on most specimens of G. aurea. In addition, the duplicate specimen at CANB has no stylar indumentum beyond the apical few $\mathrm{mm}$ while that at NSW does. We have placed this specimen with G. aurea mainly because of the NSW specimen and the flower colour, which is reported as ageing to orange-yellow.

SELECTED SPECIMENS (from 25 examined): NORTHERN TERRITORY: $17.5 \mathrm{~km}$ NNE Jabiru East, Lazarides

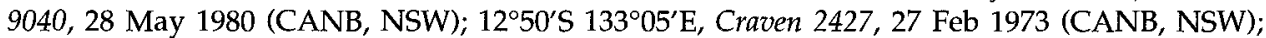
Gilruth Creek, Olsen 2697, 4 Jun 1976 (NSW, DNA); Deaf Adder Creek Gorge, Telford $7995 \mathcal{E}$ Wrigley, 22 Apr 1980 (CBG, CANB, NSW); $28.5 \mathrm{~km} \mathrm{~W}$ of Twin Falls, Lazarides 9128, 1 Jun 1980 (CANB, NSW); $31 \mathrm{~km}$ WSW Twin Falls, Craven 6393, 5 Jun 1980 (CANB, NSW); Djalkarumburr, Kakadu NP, Olde 92/37 \& 37A, 10 July 1992 (NSW, DNA, CBG, PERTH); tributary of Barramundi Creek, Thompson 514, 30 Jun 1983 (CBG, NSW, MEL, US, P, KW); c. 13.5 miles (21.6 km) N of El Sharana Mine, Lazarides 7860, 26 Feb 1973 (CANB, NSW, PERTH); Graveside Gorge, Cowie 275, 2 Jun 1985 (DNA); Deaf Adder Gorge, seedlings grown from seed sent by C.R. Dunlop, J. Forlonge s.n., 16 Sep 1980 (NSW).

Illustrations: Brennan (1986: 28, pl. 42); Brock (1988: 198, lower pl.); Elliot \& Jones (1990: xvi. [as G. longicuspis]). 


\section{Grevillea brevis $P$. Olde $\mathcal{E}$ N. Marriott, sp. nov.}

Grevilleae glabrescenti affinis, sed marginibus foliorum aut integris aut 1 -3-dentatis, pistillis brevioribus (6-12.5 mm longis), differt.

Holotype: Northern Territory: Kakadu National Park: $18.5 \mathrm{~km} \mathrm{~S}$ of Gimbat HS

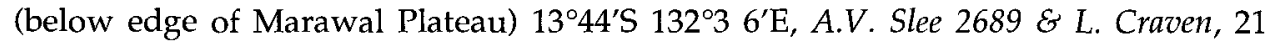
April 1990 (CANB). IsoTYPES: A, AD, BRI, DNA, K, MEL, NSW.

Synonym: G. angulata var.? lancifolia F. Muell. ex Benth. (Bentham 1870: 455). TYPE CITATION: 'Leaves oblong-lanceolate, 2 to 3 in. long.- Stony ranges, Central Australia, Herb. F. Mueller (collector not named)'. HolOTYPE (two sheets n.v.): MEL 46992 together with AD 97505501 (fide McGillivray 1993).

Seedlings: not seen. Juveniles: young leaf buds and branchlets rusty sericeous becoming quickly glabrous; young leaves sometimes glaucous; several specimens have dimorphous leaves $0.4-0.6 \mathrm{~cm}$ wide, some entirely narrow-linear, some becoming narrow-elliptic in the upper two-thirds, others entirely narrow-elliptic, broader leaves replacing the narrow leaves as the branchlet grows. Adults: single-stemmed shrubs 1-2.5 m high; branchlets angular to rounded, ridged, glabrous to sparsely sericeous. Leaves green, sometimes with a yellowish tinge in dried specimens, flat, $7-15 \mathrm{~cm}$ long, $0.6-1.5 \mathrm{~cm}$ wide, including petioles $3-7 \mathrm{~mm}$ long, glabrous, narrow-elliptic to elliptic to oblong-elliptic, either entire, or some leaves with one to three triangular spinetipped lobes (spines 1-2 mm long, brittle, non-pungent); upper and lower surfaces densely foveolate; apex acute to acuminate, non-pungent; base attenuate; venation conspicuous, more prominent on upper surface, brochidodromus when the margin entire with a secondary intramarginal vein or mixed craspedodromous when margin toothed, both types with conspicuous reticulum. Unit conflorescence $1-2 \mathrm{~cm}$ long, open to dense; primary peduncle $1-2 \mathrm{~cm}$ long, glabrous to sparsely sericeous; floral rachis $1.5-2 \mathrm{~cm}$ long, glabrous; bracts $0.7-1.3 \mathrm{~mm}$ long, $1 \mathrm{~mm}$ wide, ovate, glabrous or the margin sparsely ciliate; pedicels $3-3.5 \mathrm{~mm}$ long, glabrous, retrorse at anthesis; torus c. $1 \mathrm{~mm}$ across, oblique at $45^{\circ}$. Perianth $4.5 \mathrm{~mm}$ long, $1.5 \mathrm{~mm}$ wide, narrowly ovoid, attenuate and revolute in the upper half, glabrous outside, bearded inside (trichomes $<1 \mathrm{~mm}$ long); limb 1-1.5 mm long, $1.5 \mathrm{~mm}$ wide, spheroidal. Pistil 8-12.5 mm long; stipe 1.5-2 mm long, glabrous; style smooth, glabrous except for minute trichomes or tubercles in the apical 2-3 mm, sometimes extending further down the style; styleend not dilated beyond the base of the pollen-presenter; pollen-presenter oblong to obovate, convex; stigma central to slightly off-centre. Fruits $13-15 \mathrm{~mm}$ long, $12 \mathrm{~mm}$ wide, $10 \mathrm{~mm}$ deep, ellipsoidal, oblique to adaxially transverse to the stipe with the sutures directed outwards; pericarp c. $1 \mathrm{~mm}$ thick at centre of the suture. Seeds $7-8 \mathrm{~mm}$ long, 3.5-4 mm wide, obovoid to ellipsoid; flat on the inner face with marginal curvature and rim evident; wing $1.5-2.5 \mathrm{~mm}$ wide. Figure $1 \mathrm{f}-\mathrm{g}, \mathrm{p}-\mathrm{q}$.

EPITHET: Derived from the Latin brevis, short, in reference to the shorter pistils of this species compared to other members of this group, especially G. glabrescens.

FlOWER COLOUR: Perianth white to yellow or creamy-green. Style green to pale cream.

FLOWERING PERIOD: February-July.

Distribution: G. brevis is confined to a few areas on the eastern and western sides of the Marawal Plateau, Kakadu National Park, usually near the edge of the escarpment. Specimens have been collected in the Douglas Springs - Bloomfield Springs area and in an area south of Big Sunday (Niljanjurrung).

CONSERVATION STATUS: The species has a limited distribution entirely within Kakadu National Park but is relatively common at each site. A code of $2 \mathrm{RC} t$ is recommended. 
HaBtTAT AND ECOLOGY: Found on top or just below the top of the sandstone plateau in laterised, rocky sand in Asteromyrtus heathland or in brown, kaolinised clay mixed with laterite in broad, shallow valleys, sometimes also recorded in deep grey sandy soil. Response to fire is unknown. Pollinator unknown.

Discussion: G. brevis closely resembles G. glabrescens in its foliar and floral features and might reasonably be seen as a small-flowered subspecies. However, so marked is the difference in pistil length that, in combination with its visually distinctive leaves (some or all with the margin entire), the taxon is here regarded as a distinct species. The holotype of G. angulata var. lancifolia (MEL 46992), has entirely glabrous, entire leaves c. $1.5 \mathrm{~cm}$ wide, short, compact conflorescences $1-2 \mathrm{~cm}$ long and pistils c. 12 $\mathrm{mm}$ long with granules restricted to the style-end of an otherwise glabrous style (D. Albrecht pers. comm.). Accordingly, it is here placed in synonymy under G. brevis. The specimen at MEL includes an unattached, toothed leaf $\mathrm{c} .3 \mathrm{~cm}$ wide, somewhat wider than those on the specimens with flowers and broader than any other collection of this species. Accordingly, its status is uncertain.

VARIATION: Most of the plants from the eastern side of the Marawal Plateau have a small proportion of toothed leaves and rarely grow taller than $1.5 \mathrm{~m}$ whereas those from the eastern side of the plateau have almost all their leaves entire and often exceed $2 \mathrm{~m}$ in height. The presence of much-narrowed (usually pale green to yellow) leaves on some specimens appears to be either a virally or environmentally induced deformity. The deformity seems to be represented more in collections than is noticed on living plants (pers. obs.). We have also noted its presence on some plants of G. glabrescens. Nonetheless, a biological and ontogenetic study of its leaves would be worthwhile.

SELECTED SPECIMENS (from 22 examined): NORTHERN TERRITORY: c. 18 miles [28.8 km] SE of El Sharana Mine, Lazarides 7820, 24 Feb 1973 (CANB); source of Alligator River, Gimbat Station, Russell-Smith 728, 5 July 1983 (DNA, NSW); Kakadu National Park, Dunlop $8538 \mathcal{E}$ Munns, 21 Apr 1990 (DNA, CANB, BRI, AD, NSW, MEL); Marawal Plateau, Olde 92/32, 10 July 1992 (NSW, CBG, DNA, PERTH); escarpment above Douglas Springs, Olde 92/27, 10 July 1992 (NSW, DNA, CANB, CBG, PERTH); $5 \mathrm{~km}$ E of Ranford Hill, Russell-Smith 5659 \& Lucas, 18 Jun 1988 (DNA); $4 \mathrm{~km} \mathrm{SW}$ of Bloomfield Springs, Menkhorst 356, 13 Apr 1989 (DNA); $1 \mathrm{~km}$ NE of Bloomfield Springs, Orr 378, 20 Apr 1990 (DNA); Mary River, Bloomfield Springs, Dunlop 7078 $\mathcal{E}$ Wightman, 15 Sep 1987 (DNA); ? Central Australia (MEL 46992).

\section{Grevillea prasina McGillivray}

(McGillivray 1986: 12)

Holotype: Northern Territory: 39 miles [62.4 km] WNW of Wave Hill Police Station, R.A. Perry 2265, 27 June 1949 (CANB 108396). IsotYPES: NSW 93192, CANB 31721, AD, MEL, PERTH, BRI).

Seedlings: not seen. Juveniles: young leaves and buds rusty sericeous. Adults: spreading, multi-stemmed, lignotuberous shrubs 1-2(-3.5) $\mathrm{m}$ high; branchlets sharply angular, ridged, glabrous or rusty sericeous, sometimes sparsely sericeous; leaves bright, pale green, $3-8.5 \mathrm{~cm}$ long, $2-5 \mathrm{~cm}$ wide, including petioles $6-10 \mathrm{~mm}$ long, glabrous or rarely sparsely and minutely sericeous, usually glaucous, foveolate, ovate to broadly elliptic with 4-10 narrow-triangular, spine-tipped lobes (spines 2-3 mm long, rigid, pungent) and sinuses arcuate to rectilinear; apex acute, pungent; base cuneate; venation prominent on both surfaces, mixed craspedodromous with evident reticulum; unit conflorescence $2-5 \mathrm{~cm}$ long, dense to loose; primary peduncle $1-3 \mathrm{~cm}$ long, glabrous or sericeous; floral rachis glabrous or sericeous; bracts $1-1.5 \mathrm{~mm}$ long, 0.8-1.2 mm wide, ovate with apex acuminate and incurved, glabrous, ciliate; pedicels $2.5-4 \mathrm{~mm}$ long, glabrous or sericeous; torus c. $2 \mathrm{~mm}$ across, oblique at $20-40^{\circ}$. Perianth 5-7 mm long, $2 \mathrm{~mm}$ wide, narrowly ovoid, attenuate and revolute in the 
upper half, glabrous or sericeous outside, densely white-bearded inside, the trichomes mostly $>1 \mathrm{~mm}$ long and distributed on the upper portion of the inner tepal surface; dorsal tepals separating from the ventral tepals and reflexing strongly at anthesis; limb 1.5-2 mm long, 2-2.5 mm wide, spheroidal. Pistil 18.5-22 mm long, entirely glabrous; stipe 3-3.5 mm long; style and style-end smooth or rarely (Olde 92/65), with a few granules; pollen-presenter \pm flat, umbonate; stigma central to distally off-centre. Fruits 10-16 mm long, 7-10 mm wide, 7.5-9 mm deep, oblong-ellipsoidal, oblique to almost transverse to the stipe, sometimes erect when immature; pericarp 1-1.5 mm thick at centre face. Seeds $7-8.5 \mathrm{~mm}$ long, 2.5-4.5 mm wide, oblongellipsoidal, slightly convex on the inner face with marginal curvature evident; wing 0.5-2 $\mathrm{mm}$ wide; raphe and funiculus inconspicuous. Figure $1 \mathrm{~h}, \mathrm{r}$.

FLOWER COLOUR: Perianth green to white becoming cream to yellow after anthesis; style green ageing cream. Flowers sweetly scented.

FLOWERING PERIOD: March-September.

DistriButron: Northern Territory, extending principally from the Victoria River District south to $\mathrm{c} .17^{\circ} \mathrm{S}$ latitude and east to $\mathrm{c} .135^{\circ} 10^{\prime} \mathrm{E}$; Western Australia, extending from the Northern Territory border to the Pentecost River $\left(127^{\circ} 50^{\prime} \mathrm{E}\right)$.

CONSERVATION STATUS: Not rare.

HABITAT AND ECOLOGY: Occurs in clumps on sandstone or limestone hills usually in rocky situations or woodland extending from the ridgetops to creek beds in sandy, often skeletal soils. Regenerates from seed or lignotuber after fire. Pollinator unknown, probably birds.

VARIATION: The occurrence of plants with the pedicel, perianth and floral rachis sericeous appears to be random and we have not found any other unifying feature which warrants infraspecific division. One specimen with sericeous perianth has a glabrous floral rachis (D.J. McGillivray pers. comm.). The collection Olde 92/65A has some leaves with a minute indumentum and a few pistils with the style-end bearing a few granules or minute trichomes. This collection, growing with G. agrifolia, was not typical of the population of G. prasina at that site (cf. Olde 92/65). Larger fruits on this specimen indicate that it may be hybridised with G. agrifolia.

Selected SPECIMENS (from 25 examined): NoRTHERN TerRitory: Parakeelya Swamp, $50 \mathrm{~km}$ SW of Nathan River Homestead, Latz 10192, 29 May 1985 (DNA 78894); Cox River Station, Latz 7160, 1 Jul 1977 (NSW, NT, CANB, BRI, K, MO, B); range S of Timber Creek, P.G. Wilson 191 \& Jacobs, 6 May 1988 (PERTH, NSW 209324, DNA, K); north side of Jasper Gorge, McGillivray $3801 \mathcal{E}$ George, 15 Jun 1978 (NSW, DNA, K, PERTH, US, B); $20.8 \mathrm{~km}$ from Timber Creek on road to Kununurra, McGillivray 3805 \& George, 16 Jun 1978 (NSW, DNA); above Gibbie Creek, McGillivray 3901, 7 Jul 1978 (NSW, AD, DNA, NE, MEL, PRE, P, RSA, NY); Bullita Station, Station Hill, Wightman 2659 \& Clark, 10 Feb 1986 (DNA, NSW); 7 km N Mt Sanford Outstation, Latz 5347, 15 Jun 1974 (NT, NSW); Limbunya, Dunlop 3519, 29 Apr 1974 (DNA, CANB, PERTH). WeSTERN AustraLIA: East Kimberley; Chamberlain Gorge, El Questro Stn, Kenneally 10977, 30 Jun 1989 (PERTH, NSW); 59 km W on Wyndham - Gibb River Rd, Olde 92/65 \& 65A, 15 Jul 1992 (NSW, DNA, CBG, PERTH); South of Ernest River, Hartley 14685, 20 Mar 1978 (NSW, PERTH, CANB); Bindoola Creek, at Gibb River Rd, Hill 3363, Johnson \& Stanberg, 18 Nov 1988 (NSW, WA, CANB); 23 miles [37 km] NE of Karunjie Station, Speck 5014, 14 Sep 1954 (CANB, BRI, PERTH); $49 \mathrm{~km}$ E of Durack River between Gibb River Station and Wyndham, McGillivray 3872 $\mathcal{E}$ George, 26 Jun 1978 (NSW, PERTH, DNA, K); Cockburn Range, $46 \mathrm{~km}$ SSW of Wyndham, Lazarides 8587, 16 Mar 1978 (CANB, NSW); limestone hills west of Weaber Range, c. $50 \mathrm{~km} \mathrm{~N}$ of Kununurra, Lazarides 8424, 8 Mar 1978 (CANB, NSW, PERTH).

ILLuSTRATIOns: McGillivray (1993: 213); Petheram \& Kok (1983: 319). 
6. Grevillea agrifolia $A$. Cunn. ex $R . B r$.

(Brown 1830: 24)

LECTOTYPE: (McGillivray 1975: 24) ‘Grevillea angulata Nob Mermaids $2^{\mathrm{d}}$ Voyage No. 411 Gr. agrifolia Cunningh.' (label, in Robert Brown's script, located at lower left of the sheet); excluding the specimen at upper left labelled 'Mermaids Third Voy. No. 12' (BM, n.v.). McGillivray (1993) cites Cunningham 411 as being collected on Lacrosse Island, 18 Sep 1819.

SYNONYM: G. agrifolia var. major Ewart \& Rees (1911: 68). TYPE CITATION: Mission Station, Napier - Broome Bay, West Australia, G.F. Hill, December, 1909, No. 22' (Holo, n.v.: MEL 46989; Iso, n. v.: MEL 46990, PERTH; fide McGillivray 1993).

Seedlings (George 14563): cotyledons oblong, obtuse, midvein not evident; leaves alternate, crowded, first 2 leaves sessile, both arising very close to the cotyledons, third leaf 3-toothed, fourth leaf 5-toothed; hypocotyl 2-3 cm long, sparingly pubescent in the upper 1-2 cm, otherwise glabrous. Juveniles: new growth bronze to rusty, sericeous. Adults: single-stemmed shrubs to small trees $2-4(-6) \mathrm{m}$ tall, branchets angular to almost round, sericeous; leaves silvery-grey, grey or blue-grey, (5-)7-16 cm long, $3.5-9.5 \mathrm{~cm}$ wide, including petioles $5-13 \mathrm{~mm}$ long, densely and minutely sericeous, sometimes the indumentum sparse on the upper surface, obovate to almost round, with 1-8 scarcely evident, acuminate to broad-triangular, spine-tipped lobes (spines 1-2 mm long, brittle, usually non-pungent) with sinuses linear, sometimes arcuate; apex acute to round, sometimes emarginate; base cuneate; venation prominent on both surfaces, mixed craspedodromous to almost brochidodromous with prominent reticulum. Unit conflorescence $3-7.5 \mathrm{~cm}$ long, dense; primary peduncle $1-3.5 \mathrm{~cm}$ long; floral rachis glabrous or sericeous; bracts $1-1.8 \mathrm{~mm}$ long, $0.6-0.8 \mathrm{~mm}$ wide, ovate, glabrous or sericeous with margin ciliate, the apex acute and sometimes incurved; pedicels $2.5-4 \mathrm{~mm}$ long, glabrous or sericeous, retrorse at anthesis; torus 1.5$2.2 \mathrm{~mm}$ wide, oblique at c. $30^{\circ}$. Perianth 5-6 mm long, $2-3 \mathrm{~mm}$ wide, ovoid, strongly curved, the apex revolute, glabrous or sericeous outside, densely white-bearded inside with most trichomes $>1 \mathrm{~mm}$ long and developed on the upper portion of the tepals; dorsal tepals scarcely separating from the ventral tepals but reflexing strongly at anthesis; limb 1-1.5 mm long, 2-2.3 mm wide, spheroidal. Pistil 13.5-19 mm long; stipe 2.5-4 mm long, glabrous; style usually sparsely to moderately glandular-pubescent, or with a few trichomes restricted to the apex, or rarely entirely glabrous; style-end not dilated beyond the pollen-presenter; pollen-presenter flat, umbonate; stigma off-centre. Fruits 18-24 mm long, 14-17 mm wide, 13-16 mm deep, ellipsoidal to subglobose, erect to slightly oblique; pericarp 2-4.5 mm thick at centre face. Seeds 7.5-10 mm long, 4-5 mm wide, oblong-ellipsoidal, slightly convex on the inner face with marginal curvature and rim evident; wing 2-3.5 mm wide. Figure 1i, s.

FLOWER COLOUR: Perianth green maturing white to cream; style green maturing cream. Flowers are sweetly scented.

FLOWERING PERIOD: March-September.

Distribution: Widespread from the north-western Northern Territory to the Kimberley and adjacent off-shore islands.

CONSERVATION AND STATUS: Not rare.

HABITAT AND ECOLOGY: Found mostly in open woodland in medium to high rainfall areas where it sometimes forms clumps up to $50 \mathrm{~m}$ across (Petheram \& Kok 1983). Grows mostly in deep or shallow sandy soils but sometimes in lateritic loam. Regenerates both from seed and from epicormic buds along the stems and branchlets after low-intensity fires. Aboriginal people from Kalumburu know the species as 
'wurrgan' (Kwini language). Small brown honeyeaters have been seen probing the flowers (pers. obs.).

Discussion: G. agrifolia is distinguished by sericeous branchlets; grey-green, grey or blue-grey, obovate to almost round undulate leaves $4-9.5 \mathrm{~cm}$ wide bearing a dense, closely appressed indumentum, the margin sparingly shallow-toothed with teeth usually confined to the apical half; perianth (and pedicels) either glabrous or sericeous outside, green to white at anthesis, dorsal tepals separating at or before anthesis and reflexing to reveal a conspicuous, densely villous beard on the inner surface, the longest trichomes of which are $>1 \mathrm{~mm}$ long; pistil 13.5-19 mm long, ovarian stipe $2.5-4 \mathrm{~mm}$ long, the style usually bearing a moderately dense indumentum of erect, mixed biramous and glandular trichomes along its whole length, rarely almost glabrous; fruits $18-23 \mathrm{~mm}$ long, ellipsoidal to obovoidal, erect or slightly oblique to the stipe; pericarp $2.5-4.5 \mathrm{~mm}$ thick at centre face.

G. agrifolia differs from $G$. angulata which has generally narrower, green, oblong leaves usually with a less conspicuous vestiture and with the margin usually dentate with teeth extending almost to the leaf base, and smaller, more oblique fruits with a much thinner pericarp. Although most specimens of G. agrifolia also possess a moderately dense, though inconspicuous stylar indumentum, thereby providing an obvious distinguishing character, some specimens (e.g. Keighery 4780) have the indumentum restricted to the style-end, while yet others are glabrous except for an occasional trichome (e.g. George 13485).

VARIATION: The varietal status of G. agrifolia var. major is not restored from synonymy in this revision, although plants from Napier Broome Bay (type locality of var. major) differ from the type of G. agrifolia in the sericeous outer surface of the perianth (glabrous in the type of G. agrifolia). The other two elements of the original delimitation of var. major (larger leaves and larger fruits) are not supported by more recent collections from the same area and elsewhere among which are several specimens with leaves and fruits about the same size as var. major but with the perianth glabrous outside. The geographic distribution of specimens referable to a notional G. agrifolia var. major, i.e. with the outer perianth surface sericeous, appears to be random, although most collections are from the western sector of the species' range. However, our observation of plants in this area (limited to between Kalumburu and the Gibb River Rd) show both types are present with a greater proportion of plants with flowers with a sericeous outer perianth surface. At one site $(204 \mathrm{~km}$ west on Gibb River - Wyndham Rd [Olde 92/69 \& 92/70]), plants clearly of the same species occur together, some with the outer perianth surface glabrous, some sericeous.

Within Grevillea agrifolia there is some variability in leaf size, colour, degree of toothing and indumentum density. The major differences, however, are noted in perianth and stylar indumentum. Most specimens with a sericeous outer perianth have been collected between the coast and $15^{\circ} \mathrm{S}$ latitude and between $126^{\circ}$ and $127^{\circ} \mathrm{E}$ longitude.

SEleCted SPECIMENS (from 154 examined): NORTHERN TERRITORY: 120 miles [192 km] W of Timber Creek, Maconochie 1126, 19 Jun 1971 (NSW , PERTH, CANB, AD, NT); 101 miles (161.5 km) SE Carlton Station, R.A. Perry 3003, 23 Jul 1952 (NSW, PERTH, MEL, BRI, AD, CANB); $20.5 \mathrm{~km}$ E of Keep River on Kununurra - Katherine Road, McGillivray 3788 \& George, 14 Jun 1978 (NSW); $4.5 \mathrm{~km}$ from SE edge of Pinkerton Range on road to Bullo River, McGillivray 3887 \& Petheram, 29 Jun 1978 (NSW, PERTH, K, DNA, NY, LE, PRE). WESTERn Australia: Camp Creek Gauging Station, Mitchell Plateau, Keighery 4780, 23 April 1980 (PERTH); Yowradaggi River, 18 km S of Cockatoo Island, Yampi Sound, Fell 267, 3 Sep 1984 (PERTH); near The Rocks, King Leopold Ranges, Lazarides 6454, 29 Jul 1959 (CANB, PERTH, NSW, MEL, BRI); $20 \mathrm{~km}$ N of Kalumburu Mission, Fryxell \& Craven 4118, 14 May 1983 (CANB, PERTH); Boomerang Bay, Bigge Island, Marchant 72/28, 1 Jun 1972 (PERTH); Byam Martin Island, P.G. Wilson 11492, 11 Jul 1973 (PERTH); gorge W of 'Silent Grove' homestead, Hill 3430, 23 Nov 1988 (NSW, PERTH); Hidden Valley 
NP, Kununurra, Blaxell 88/055 \& Wrigley, 18 Jul 1988 (NSW); $59 \mathrm{~km} \mathrm{~W}$ on Wyndham - Gibb River Rd, Olde 92/64, 15 Jul 1992 (NSW); King Edward River Crossing on road to Mitchell Plateau, Olde 92/80, 16 Jul 1992 (NSW); $204 \mathrm{~km} \mathrm{~W} \mathrm{on} \mathrm{Wyndham} \mathrm{-} \mathrm{Gibb} \mathrm{River} \mathrm{Rd,} \mathrm{Olde} \mathrm{92/69} \mathrm{\&}$ 70, 15 July 1992 (NSW); 2.9 km SE Mitchell Plateau Mining Camp, George 14501, 23 Apr 1977 (NSW, CANB, PERTH, LE, K); Airfield Swamp, Mitchell Plateau, Kenneally 6581, 15 May 1978 (PERTH); Mount House Station, Beard 4144, 17 May 1965 (NSW, PERTH, KPWA); Napier Broome Bay, West Governor Is, Forbes 2060, 19 May 1984 (NSW, PERTH, CANB); tributary of Camp Creek, Mitchell Plateau, Kenneally 7781, 18 Jan 1982 (PERTH); Boiga Falls, Drysdale River National Park, Kenneally 3028, 3 Aug 1975 (PERTH); above Mogurnda Ck, Drysdale River NP, George 13485, 6 Aug 1975 (PERTH); Cracticus Falls, Drysdale River NP, Kenneally 4219, 11 Aug 1975 (PERTH).

IlLuSTRATIONS: Brock (1988: 197); McGillivray (1993: 210); Petheram \& Kok (1983: 317).

\section{Grevillea microcarpa $P$. Olde $\mathcal{E} N$. Marriott, sp. nov.}

$\mathrm{Ab}$ Grevillea agrifolia fructibus minoribus (11-15 mm longis), foliis adultis brevioribus angustioribusque (plerumque $<8 \mathrm{~cm}$. longis et $<4 \mathrm{~cm}$ latis) olivaceisque (non cyaneocanis) distinguitur.

Holotype: Western Australia: Northern Kimberley: King Edward Crossing on road to Mitchell Plateau, $15^{\circ} 05^{\prime}$ S $126^{\circ} 15^{\prime} \mathrm{E}, P$. \& G. Keane s.n., July 1991 (NSW). IsOTYPES: PERTH, CBG, DNA.

Seedlings: not seen. Juveniles: new growth ferrugino-sericeous, densely ferruginous along the midvein. Adults: bushy shrubs $1-2.5 \mathrm{~m}$ tall, 2-3 m wide; branchlets angular, becoming rounded with age, ferrugino-sericeous; leaves olive-green, $0.5-7.5(-9) \mathrm{cm}$ long, 0.5-4 (-5) $\mathrm{cm}$ wide, including petioles 2-10 $\mathrm{mm}$ long, obovate to elliptic, densely to sparsely minute-sericeous on both surfaces, margin either entire or with 1-7 irregular, spine-tipped, subtriangular lobes (spines 1-2 $\mathrm{mm}$ long, brittle, scarcely pungent) and rectilinear or shallow-arcuate sinuses; leaf base cuneate; apex acute, sometimes pungent; venation prominent on both sides, mixed craspedodromous with reticulum evident. Unit conflorescence $2.5-5 \mathrm{~cm}$ long, dense; primary peduncles $0.5-3 \mathrm{~cm}$ long, sericeous; floral rachises sericeous; bracts $1 \mathrm{~mm}$ long, $1 \mathrm{~mm}$ wide, ovate, sericeous outside, apex acute, incurved; pedicels $2.5-3 \mathrm{~mm}$ long, sericeous, patent to retrorse; torus $2 \mathrm{~mm}$ across, oblique at c. $45^{\circ}$. Perianth $4-5 \mathrm{~mm}$ long, $2.5 \mathrm{~mm}$ wide, narrowly ovoid, strongly curved, sericeous or sparsely so outside, densely bearded inside with most trichomes $>1 \mathrm{~mm}$ long; limb $1.5 \mathrm{~mm}$ long, $2 \mathrm{~mm}$ wide, spheroidal, sericeous. Pistil 15-18(-20) mm long; stipe 3.5-4 mm long, glabrous; style entirely glabrous or sparsely pubescent; style-end glabrous, not dilated beyond the pollen-presenter; pollen-presenter flat, umbonate. Fruits 11-15 mm long, 10-12 mm wide, 9-10 $\mathrm{mm}$ deep, ellipsoidal, erect to slightly oblique on stipes; pericarp $0.8-1.5$ $\mathrm{mm}$ thick at centre face. Seeds $7-8 \mathrm{~mm}$ long, $3.5 \mathrm{~mm}$ wide, obovoidal, faintly rugose; inner face convex with marginal rim; seed wing 1.5-2 mm wide. Figure 1j, t.

EPITHET: Derived from the Greek micro, small, and carpos, fruit, in reference to the small fruits of this species (by comparison with those of G. agrifolia.)

FLOWER COLOUR: Perianth green becoming white at anthesis, ageing to cream or yellow; style green, ageing cream with green tip. Flowers are sweetly perfumed.

FLOWERING PERIOD: May-July, possibly longer.

DistRibution: G. microcarpa is confined to a small area in the northern Kimberley extending from Napier Broome Bay to the lower King Edward and Drysdale Rivers.

CONSERVATION STATUS: Locally common but its distribution is restricted and a code of $3 R$ is recommended. 
HABITAT AND ECOLOGY: Occurs around sandstone outcrops either in crevices or in gravelly sand, on hillsides or in and near creek lines. Fire response unknown. Pollinator probably birds. Aboriginal people from Kalumburu did not differentiate this species from G. agrifolia in their language.

Discussion: The sympatric occurrence at King Edward River Crossing and NW of Kalumburu, Western Australia, of the visually distinct G. microcarpa with G. agrifolia is seen by us as clear grounds for separation of $G$. microcarpa at specific rank. Although G. microcarpa seems closely related to G. angulata through its smaller, thinner-walled fruits, its closest affinity is certainly with $G$. agrifolia. It differs from G. angulata in its sericeous outer perianth, its smooth style-end, its (usually) more erect fruits and from G. agrifolia in its smaller fruits (11-15 $\mathrm{mm}$ long) with the pericarp 0.8-1.5 mm thick at centre face, in its lower-growing, shrubby habit, and in its smaller leaves (both narrower (mostly $3-3.5 \mathrm{~cm}$ wide) and shorter (mostly $<7.5 \mathrm{~cm}$ long), which are also of a slightly different colour (olive-green to grey-green). In the area of its sympatric occurrence with G. agrifolia, the style of G. microcarpa is either glabrous or sparsely hairy whereas that of $G$. agrifolia is inconspicuously hairy over its entire length.

G. microcarpa is also closely related to G. prasina with which it shares similar-sized fruits, and, in some collections, entirely glabrous pistils but it differs in its branchlet cross-sectional shape, its leaf colour, indumentum and shape and in its fruit shape. In G. prasina, the branchlets are sharply angular and usually ridged, the leaves are always bright green, glabrous or sparsely sericeous and mostly ovate with pungent toothing; the fruits are oblong-ellipsoidal and usually very oblique to the stipe. Consideration was given to the likelihood that $G$. microcarpa represented a hybrid swarm with G. agrifolia and G. prasina as the putative parents. However, G. microcarpa is distributed over a considerable area in disjunct, relatively homogeneous populations north of the (current) distribution of G. prasina and given the consistency of features enumerated here seems to us to represent a distinct species.

VARIATION: There is little foliage variation in G. microcarpa except for the number of leaf lobes, which usually range from 2-5. Stylar indumentum is either entirely lacking or sparse, usually with mixed biramous and glandular trichomes. The style-end is always glabrous or with an occasional solitary trichome.

Selected specimens (from 12 examined): Western Australia: Kimberley; Northern Province; 4 km NW Kalumburu, McGillivray 3860 \& George , 24 Jun 1978 (NSW, PERTH, K, US); c. 50 km NE of Mitchell River H.S., King Edward River, Beauglehole 58920 \& Errey 2620, 23 Aug 1978 (NSW, PERTH); western Side of Kalumburu Rd, $16 \mathrm{~km} \mathrm{~S}$ of Carson River, McGillivray $3864 \mathcal{E}$ George, 25 Jun 1978 (NSW, PERTH, K); near King Edward River, off northern road from Mitchell Plateau to Kalumburu, Turner s.n., May 1985 (NSW); camping area on King Edward River off Mitchell Plateau Rd, Marriott 9027, 19 Jun 1990 (NSW); Woppinbie Creek, 4 km SW from mouth of Napier Broome Bay, Forbes 2136, 24 May 1984 (MEL, NSW, PERTH); Solea Fall, Drysdale River NP, George 13741, 12 Aug 1975 (PERTH); Coucal Gorge, Carson Escarpment, Drysdale River NP, George 13838, 15 Aug 1975 (PERTH). 


\section{Acknowledgements}

We wish to pay special thanks to Philip and Glenys Keane who collected specimens for us in the Kimberley in June/July 1991. Don McGillivray also gave information and made available a manuscript of his revision of the genus Grevillea, from which some typification details of previously named species were drawn. We are especially grateful to Dr Peter Weston, Bob Makinson and Don McGillivray who critically read earlier drafts of this manuscript and to the Directors of the following institutions for giving access to their collections as visiting worker or through specimen loans: NSW, CANB, CBG, DNA, PERTH. Mr Jack Kardady of Kalumburu provided information on Aboriginal plant names. Dr Jeremy Russell-Smith, Kym Brennan and John de Konig all gave valuable assistance with field work in the Northern Territory, especially in Kakadu National Park. Mr David Albrecht was a most helpful liaison at MEL.

This research was funded by a grant from the Society for Growing Australian Plants (NSW) Limited and by the Newcastle Group of the same Society.

\section{References}

Bentham, G. (1870) Flora australiensis, vol. 5 (Reeve \& Co.: London)

Brennan, K. (1986) Wildflowers of Kakadu. (The author: Jabiru, N.T.)

Briggs, B.G. \& Johnson, L.A.S. (1979) Evolution in the Myrtaceae - evidence from the inflorescence structure. Proc. Linn. Soc. New South Wales 102: 157-256.

Briggs, J.D. \& Leigh, J.H. (1988) Rare or threatened Australian plants. Austral. Nat. Parks \& Wildlife Service, Special Publication No 14.

Brock, J. (1988) Top end native plants. (The author: Winnellie, N.T.)

Brown, R. (1830) Supplementum primum prodromi florae Novae Hollandiae (Richard Taylor: London).

Chaloupka, G. \& Giuliani, P. (1968) Gundulk Abel Gundalg, Mayali Flora. Unpublished MS 1968, Aust. Instit. Aboriginal Studies, Canberra.

Elliot, W.R. \& Jones, D.L. (1990) Encyclopaedia of Australian plants, vol. 5 (Lothian: Melbourne)

Ewart, A.J., Rees, B. \& Wood, B. (1911) Contributions to the Flora of Australia, No. 17. Proc. Roy. Soc. Victoria 24(1): 61-75.

Hickey L.J. (1973) Classification of the architecture of dicotyledonous leaves. Amer. J. Bot. 60: $17-33$.

Johnson, L.A.S. \& Briggs, B.G. (1975) On the Proteaceae - the evolution and classification of a southern family. Bot. Journ. Linn. Soc. 70: 83-182.

McGillivray, D.J. (1975) Australian Proteaceae: New taxa and notes. Telopea 1(1): 19-32.

McGillivray, D.J. (1986) New names in Grevillea. (The author: Castle Hill, N.S.W.)

McGillivray, D.J. (1993) Grevillea. (Melbourne University Press: Melbourne)

Makinson R.O. (1991) Grevillea. Pp. 31-35 in G. Harden (ed.) Flora of New South Wales vol. 2.

Petheram, R.J. \& Kok, B. (1983) Plants of the Kimberley region of Western Australia. (Uni. of W.A. Press: Perth)

Smyth, D.M. \& von Sturmer, J.R. (1981) The use of plants by Aboriginal people in the Oenpelli region of western Arnhem Land. Unpublished MS 3403, Aust. Instit. Aboriginal Studies, Canberra. 